\title{
GAMBARAN PENGETAHUAN DAN PERILAKU CUCI TANGAN PAKAI SABUN (CTPS) PADA SISWA SEKOLAH DASAR DI WILAYAH KERJA PUSKESMAS NEGARA RATU KECAMATAN SUNGKAI UTARA KABUPATEN LAMPUNG UTARA TAHUN 2019
}

\begin{abstract}
Anisa Fitri ${ }^{1)}$
Abstrak

Mencuci tangan adalah kegiatan yang umum dilakukan manusia di dunia. Tapi membasuh tangan dengan air saja tidaklah cukup. Cuci Tangan Pakai Sabun (CTPS) merupakan upaya yang direkomendasikan untuk mencegah penyakit, dengan pertimbangan bahwa sabun mudah diperoleh dan terjangkau. Selain itu, air mengalir dapat diupayakan hampir di setiap rumah tangga. Supaya efektif, perilaku CTPS juga perlu dilakukan dengan benar.

Tujuan penelitian ini adalah untuk Mengetahui Gambaran Pengetahuan dan Perilaku Cuci Tangan Pakai Sabun (CTPS) Pada Siswa Sekolah Dasar Di wilayah Kerja Puskesmas Negara Ratu tahun 2019. Jenis penelitian yang di gunakan adalah deskriptif yaitu menggambarkan pengetahuan dan perilaku Cuci Tangan Pakai Sabun (CTPS) pada siswa SD yang berada di wilayah kerja Puskesmas Negara Ratu. populasi dalam penelitian ini adalah siswa sekolah dasar kelas IV dan V yang di ambil dari 3 sekolah dasar untuk mendapatkan sampel 96 siswa di Wilayah Kerja Puskesmas Negara Ratu.

Hasil penelitian melaporkan dari 96 responden yang berasal dari 3 sekolah dasar, diketahui bahwa 52 responden $(54,2 \%)$ yang memiliki pengetahuan baik, tidak terdapat fasilitas di sekolah dasar, dan 44 responden $(45,8 \%)$ yang memiliki perilaku baik. Puskesmas Natar agar melakukan penyuluhan lebih intensif sehingga pengetahuan dan perilaku cuci tangan pakai sabun pada siswa di sekolah dasar lebih meningkat dan melakuan advokasi kepada pihak sekolah agar membangun fasilitas cuci tangan pakai sabun.
\end{abstract}

Kata kunci : CTPS, pengetahuan, sekolah dasar

1) Alumni Jurusan Kesehatan Lingkungan Poltekkes Kemenkes Tanjungkarang

\section{PENDAHULUAN}

Pengetahuan merupakan hasil yang dikemukakan oleh seseorang yang merupakan hasil dari tahu. Hal ini dapat terjadi setelah orang tau individu melakukan penginderaan terhadap objek tertentu. Pengindraan terjadi melalui panca indera manusia, yakni indera pengelihatan, pendengaran, penciuman, rasa dan raba.Sebagian besar hasil penginderaan manusia diperoleh melalui mata dan telinga, (Notoatmodjo, 2003:121).

Perilaku kesehatan adalah suatu respon seseorang (organisme) terhadap stimulus atau objek yang berkaitan dengan sakit atau penyakit, sistem pelayanan kesehatan, makan dan minum, serta lingkungan. Perilaku kesehatan dapat dikelompokan menjadi 3 kelompok yaitu:

1. Perilaku memelihara kesehatan,

2. Perilaku mencari pengobatan dan

3. Perilaku terhadap lingkungan.
Bentuk perilaku kesehatan yang dapat dilakukan seseorang untuk memelihara atau menjaga kesehatan agar tidak sakit serta usaha mencari pertolongan untuk pemulihan kesehatan jika menderita suatu penyakit. Salah satu bentuk penerapan memelihara kesehatan adalah dengan melakukan Perilaku Hidup bersih dan Sehat/PHBS, (Notoatmodjo, 2012:132).

PHBS disekolah adalah sekempulan perilaku yang di praktikkan oleh peserta didik, guru dan masyarakat lingkungan sekolah atas dasar kesadaran sebagai hasil belajar, sehingga secara mandiri mampu mencegah penyakit, meningkatkan kesehatannya, serta berperan aktif dalam mewujudkan lingkungan yang sehat.Anak sekolah merupakan generasi penurus bangsa yang perlu dijaga, ditingkatkan dan dilindungi kesehatannya. Jumlah usia sekolah yang cukup besar yaitu 30\% dari jumlah penduduk Indonesia merupakan masa keemasan untuk menanamkan PHBS sehingga 
anak sekolah berpotensi sebagai agen perubahan untuk mempromosikan PHBS, baik dilingkungan sekolah, keluarga maupun masyarakat. Dengan menerapkan PHBS disekolah oleh peserta didik, guru, dan masyarakat lingkungan sekolah,maka akan membentuk mereka untuk memiliki kemampuan dan kemandirian dalam mencegah penyakit, meningkatkan kesehatannya, serta berperan aktif dalam mewujudkan lingkungan sekolah yang sehat (Proverawati dan Rahmawati, 2012:22).

Munculnya berbagai penyakit yang sering menyerang anak usia sekolah (6-12 tahun), ternyata umumnya berkaitan dengan PHBS. Penanaman nilai-nilai PHBS disekolah merupakan kebutuhan mutlak dan dapat dilakukan melalui pendekatan usaha kesehatan sekolah (UKS). PHBS disekolah adalah upaya untuk memberdayakan siswa, guru dan masyarakat lingkungan sekolah agar tahu,mau dan mampu mempraktikkan PHBS dan berperan aktif dalam mewujudkan sekolah yang sehat. Berikut adalah indikator PHBS disekolah yang meliputi :

1. Mencuci tangan dengan air yang mengalir dan memakai sabun

2. Mengkonsumsi jajanan sehat di kantin sekolah

3. Menggunakan jamban yang bersih dan sehat

4. Olahraga yang teratur dan terukur

5. Memberanta jentik nyamuk

6. Tidak merokok disekolah

7. Menimbang berat badan dan mengukur tinggi badan setiap bulan

8. Membuang sampah pada tempatnya

Perilaku Cuci Tangan Pakai Sabun (CTPS) yang merupakan salah satu Perilaku Hidup Bersih dan Sehat (PHBS), saat ini juga telah menjadi perhatian dunia, hal ini karena masalah kurang nya praktek perilaku cuci tangan tidak hanya terjadi di negara - negara berkembang saja, ternyata di negara - negara maju pun kebanyakan masyarakatnya masih lupa untuk melakukan perilaku cuci tangan, (Depkes, 2008).

Untuk mendapatkan hasil yang optimal, maka mencuci tangan haruslah dengan air bersih yang mengalir, baik itu melalui kran air atau disiram dengan gayung, menggunakan sabun yang standar, setelah itu keringkan dengan handuk bersih atau menggunakan tisu, (Kemenkes, 2014).
Mencuci tangan dengan air yang tidak bersih bnayak mengandung kuman dan bakteri penyebab penyakit. Bila digunkan, kuman akan pindah pada saat makan kuman dengan cepat masuk kedalam tubuh, dan bisa menimbulkan penyakit. Sabun dapat membersihkan dan membunuh kuman, karena tanpa sabun kotoran dan kuman masih tertinggal di tangan, kebiasaan mencuci tangan dengan sabun dengan benar dapat menurunkan separuh $(50 \%)$ dari penderita diare.

Keterkaitan perilaku mencuci tangan dengan sabun dan penyakit diare, penelitian intervensi, kontrol kasus,dan lintas sektor dilakukan menggunakan data elektronik dan data yang terkumpul menunjukkan bahwa risiko relatif yang didapat dari tidak mencuci tangan dari percobaan intervensi adalah 95\% menderita diare, dan mencuci tangan dengan sabun dapat mengurangi risiko diare hingga 47\%, ("Mencuci Tangan DenganSabun":Wikipedia).

Penyakit diare masih menjadi salah satu masalah kesehatan masyarakat yang penting karena merupakan penyumbang utama ketiga angka kesakitan dan kematian anak di berbagai negara belahan dunia termasuk indonesia, sehingga dunia melaluli WHO (World Health Organitation) pada tahun 1984 menetapkan diare sebagai kedaruratan global, (Kemenkes RI, 2011).

Mencuci tangan dengan sabun adalah salah satu cara paling efektif untuk mencegah penyakit diare dan ISPA,yang keduanya menjadi penyebab utama kematian anak anak. Setiap tahun, sebanyak 3,5 juta anakanak diseluruh dunia meninggal sebelum mencapai umur lima tahun karena penyakit diare dan ISPA. Mencuci tangan dengan sabun juga dapat mencegah infeksi kulit, mata, cacing yang tinggal didalam usus, Severe Acute Respiratory Syndrome, dan flu burung. Tujuan penelitian adalah mengetahui Pengetahuan dan Perilaku Cuci Tangan Pakai Sabun (CTPS) Pada Siswa Sekolah Dasar Di wilayah Kerja Puskesmas Negara Ratu tahun 2019.

\section{METODE}

Penelitian ini merupakan penelitian yang bersifat deskriptif, dengan tujuan mengetahui pengetahuan dan perilaku dalam cuci tangan pakai sabun (CTPS) di Sekolah Dasar yang berada di wilayah kerja Puskesmas Negara Ratu. Populasi dalam penelitian ini adalah siswa siswi kelas IV dan V yang berasal dari 3 
sekolah dasar. Sampel ini di ambil dari jumlah populasi yaitu 96 siswa. Data dikumpulkan pada bulan Maret-April 2019. Data di analisis secara univariat, dimana hasil yang di peroleh disajikan dalam bentuk tabel, narasi dan distribusi frekuensi.
HASIL

Hasil penelitian yang dilakukan dengan total 96 responden dari 3 Sekolah Dasar untuk mengetahui tingkat pengetahuan dan perilaku Cuci Tangan Pakai Sabun (CTPS) pada siswa kelas IV dan V di sekolah dasar wilayah kerja puskesmas negara ratu dengan alat bantu merupakan angket (Tabel 1).

Tabel 1. Distribusi responden berdasarkan Jenis Kelamin, Jumlah Siswa dan Sekolah Dasar

\begin{tabular}{|c|c|c|c|c|c|c|}
\hline \multirow{3}{*}{ No. } & \multirow{3}{*}{ Nama Sekolah Dasar } & \multicolumn{4}{|c|}{ Kelas } & \multirow{3}{*}{ Jumlah } \\
\hline & & \multicolumn{2}{|c|}{ IV } & \multicolumn{2}{|c|}{$\mathrm{V}$} & \\
\hline & & $\mathrm{L}$ & $\mathrm{P}$ & $\mathrm{L}$ & $\mathrm{P}$ & \\
\hline 1. & SD Negeri 1 Negara Ratu & 8 & 8 & 12 & 4 & 32 \\
\hline 2. & SD Negeri Ciamis & 7 & 9 & 13 & 3 & 32 \\
\hline 3 & SD Negeri 1 Baturaja & 9 & 7 & 12 & 4 & 32 \\
\hline & & & & & & 96 \\
\hline
\end{tabular}

\section{Pengetahunan CPTS}

Tabel 2. Tingkat Pengetahuan CTPS

\begin{tabular}{llll}
\hline No & Pengetahuan & Jumlah & Persentase \\
\hline 1 & Baik & 52 & 54,2 \\
2 & Buruk & 44 & 45,8 \\
& Total & 96 & 100,0 \\
\hline
\end{tabular}

Berdasarkan tabel 2, diketahui bahwa sebagian besar responden memiliki tingkat pengetahuan baik yaitu sebanyak 52 responden $(54,2 \%)$. Sedangkan responden yang memiliki pengetahuan buruk sebanyak 44 responden $(45,8 \%)$.

\section{Fasilitas CPTS}

Berdasarkan hasil penelitian yang dilaporkan bahwa belum ada sekolah dasar yang memiliki sarana cuci tangan, seperti sekolah yang belum memiliki tempat cuci tangan di setiap kelas, dan tidak menyediakan sabun cuci tangan (handsoap) di sekolah dasar di wilayah kerja Puskesmas Negara ratu.

\section{Perilaku CPTS}

Tabel 3 Distribusi Perilaku Cuci Tangan Pakai Sabun (CTPS)

\begin{tabular}{clll}
\hline No & Variabel & Jumlah & Persentase \\
\hline 1 & Ya & 44 & 45,8 \\
2 & Kadang & 15 & 15,6 \\
3 & Tidak & 37 & 38,5 \\
\hline & Total & 96 & 100,0 \\
\hline
\end{tabular}

Dari tabel 3 diketahui bahwa sebagian responden memiliki perilaku yang baik dalam melakukan CTPS yaitu sebanyak 44 responden (45,8\%). Sedangkan yang kadang - kadang melakukan CTPS yaitu sebanyak 15 responden $(15,6 \%)$, dan yang tidak melakukan CTPS yaitu sebanyak 37 responden $(38,5 \%)$.

\section{PEMBAHASAN}

Berdasarkan hasil penelitian yang dilakukan oleh peneliti pada bulan april tahun 2019 dengan 96 responden dari 3 Sekolah Dasar pada murid kelas IV dan V pada Sekolah Dasar di wilayah kerja Puskesmas Negara Ratu.

\section{Pengetahuan CTPS}

Berdasarkan hasil penelitian terhadap 96 responden 3 Sekolah dasar di ketahui bahwa sebanyak 52 responden $(54,2 \%)$ telah memiliki tingkat pengetahuan yang baik. Mengingat masih banyak responden yang memiliki tingkat pengetahuan yang kurang baik terhadap Cuci Tangan Pakai Sabun (CTPS) yaitu sebanyak 44 responden $(45,8 \%)$ maka masih dibutuhkan bimbingan terhadap para siswa oleh orang tua,guru, maupun petugas kesehatan setempat demi terlaksananya Perilaku Hidup Bersih dan Sehat pada anak usia sekolah.

Dengan tingkat pengetahuan yang baik terhadap Cuci Tangan pakai Sabun (CTPS) diharapkan siswa mampu menjaga dirinya sendiri dari penyakit berbasis lingkungan. Pendidikan merupakan suatu usaha untuk mengembangkan kepribadian dan kemampuan di dalam dan diluar sekolah dan berlangsung 
seumur hidup. Pendidikan sangat mempengaruhi proses belajar makin tinggi pendidikan seseorang, maka makin tinggi pula informasi yang didapatkan. Makin banyak informasi yang didapat oleh siswa tentang pentingnya Cuci Tangan Pakai Sabun (CTPS) makin baik perilaku siswa tersebut. Agar hal tersebut dapat terlaksana maka hendaknya guru, orang tua, dan petugas kesehatan selalu memberikan contoh pelaksanaan perilaku Cuci Tangan Pakai Sabun di lingkungan siswa dalam kehidupan sehari - hari. Memiliki tingkat pengetahuan yang baik terhadap perilaku Cuci Tangan Pakai Sabun (CTPS) sangatlah penting pada masa usia sekolah. Hal ini dikarnakan banyaknya interaksi anak usia sekolah dengan lingkungan didalam kehidupan sehari - hari yang dapat menimbulkan penyakit berbasis lingkungan apabila tidak memiliki pengetahuan yang baik tentang Cuci Tangan Pakai Sabun (CTPS). Diharapkan keluarga dapat membantu memberikan pengetahuan Cuci Tangan Pakai Sabun (CTPS) terutama di lingkungan keluarga agar secara berangsur - angsur siswa yang telah memiliki tingkat pengetahuan yang baik dapat memberikkan dampak positif secara meluas kepada masyarakat dan dapat menurunkan penyakit berbasis lingkungan khususnya pada wilayah kecamatan sungkai utara.

Agar hal tersebut dapat terlaksana sebaiknya guru, orang tua, dan petugas kesehatan selalu memberikan contoh pelaksanaan dalam kehidupan sehati - hari dan memberikan kan pengetahuan tentang penting nya Cuci Tangan Pakai Sabun (CTPCS) di masa usia sekolah. Faktor kebiasaan sangat mendominasi perilaku seseorang, apabila seorang anak di biasakan untuk Cuci Tangan Pakai Sabun (CTPS) dengan dasar tingkat pengetahuan yang baik, maka anak tersebut dapat memproteksi diri mereka sendiri dari penyakit berbasis lingkungan.

\section{Fasilitas CTPS}

Berdasarkan hasil penelitian yang dilakuan oleh peneliti belum ada sekolah dasar yang memiliki tempat cuci tangan, seperti sekolah yang belum memiliki tempat cuci tangan di setiap kelas, dan tidak menyediakan sabun cuci tangan (handsoap) di sekolah dasar di wilayah kerja Puskesmas Negara ratu.

Mencuci tangan bertujuan untuk melepaskan atau membunuh patogen mikroorganisme (kuman) dalam mencegah perpindahan mereka pada siswa. Penggunaan air saja dalam mencuci tangan tidak efektif untuk membersihkan kulit karena air terbukti tidak dapat melepaskan minyak, lemakn dan protein dimana zat - zat ini merupakan bagian dari kotoran organik.

Mencuci tangan adalah proses yang secara mekanis melepaskan kotoran dan debris dari kulit tangan dengan menggunakan sabun biasa dan air. Tujuan mencuci tangan adalah merupakan salah satu unsur pencegahan penularan infeksi. Perilaku mencuci tangan adalah masalah yang dianggap mudah. Begitu mudah nya sehingga banyak orang mengabaikannya, padahal perilaku mencuci tangan mampu mencegah berbagai jenis penyakit. Kurangnya akses untuk air bersih mengakibatkan penurunan tingkat kehadiran siswa di sekolah dasar, karena tidak adanya fasilitas sanitasi yang memadai. Akses air bersih dan sanitasi merupakan dasr penting untuk kehidupan anak - anak di seluruh dunia dilihat dari segi kesehatan, kelangsungan hidup, dan rasa penghargaan terhadap diri mereka. Penyediaan air bersihdan perilaku sanitasi yang baik disekolah juga menjadi salah satu cara untuk mencapai tujuan.

Air bersih penting untuk menunjang pembersihan dalam kehidupan, banyak sekali standar kesehatan mengenai air terutama yang berhubungan dengan air minum dan untuk kesehatan, termasuk di dalamnya air yang bebas mikroorganisme, bahan kimia, dan bahan radioaktif. Namun untuk keperluan mencuci tangan bagi masyarakat, maka dengan kriteria yang disebutkan yakin jernih,tidak berwarna dan tidak berbau sudah cukup untuk keperluan mencuci tangan.

\section{Perilaku CTPS}

Berdasarkan hasil penelitian yang telah di lakukan terhadap 96 responden dari 3 Sekolah Dasar mengenai perilaku Cuci Tangan Pakai Sabun (CTPS) diketahui bahwa 44 responden $(45,8 \%)$ telah memiliki perilaku yang baik. Responden yang baik ini dapat terjadi karena sebagian besar responden telah memiliki tingkat pengetahuan tentang Cuci Tangan Pakai Sabun (CPTS) dengan baik. Namun mengingat perilaku responden yang masih kurang baik dibutuhkan bimbingan dari keluarga, orangtua, guru, petugas kesehatan, masyarakat untuk memotivasi siswa dalam berperilaku Cuci Tangan Pakai Sabun (CTPS) sejak dini.

Anak - anak merupakan kelompok yang paling rentan terhadap perilaku yang tidak sehat. Padahal anak - anak merupakan aset 
bangsa yang sangat penting bagi masa mendatang. Dengan perilaku yang baik diharapkan siswa mampu menjaga dirinya sendiri agar terhindar dari penyakit berbasis lingkungan. Adanya hubungan bermakna antara pengetahuan dan perilaku seseorang tentang CTPS dapat terjadi karenakan salah satu faktor yang mempengaruhi perilaku seseorang adalah tingkat pengetahuan. Seperti dikemukakan dalam teori bahwasanya perilaku seseorang tentang kesehatan ditentukan oleh pengetahuan. Pengetahuan merupakan faktor pemudah (predisposing factor) dalam pelaksananan CTPS (Notoatmodjo, 2003:13).

Dalam teori tersebut pengetahuan merupakan hal yang sangat penting, anak usia sekolah sangat diharapkan untuk memiliki pengetahuan yang baik dalam CTPS sehingga dalam kehidupan sehari - hari akan dapat dilakukan dengan mudah karena mengetahui manfaat yang akan didapat dari penerapan CTPS dalam kehidupan mereka. Jika perilaku CTPS ini telah dilakukan oleh keluarga, diharapkan secara berangsur - angsur dapat memotivasi masyarakat dalam penurunan penyakit berbasis lingkungan. Perilaku CTPS ini sangat penting bagi anak usia sekolah dasar, karena dengan menerapkan perilaku CTPS dimanapun mereka berada akan sangat mengurangi penularan penyakit melalui tangan.

Sumber penyebab penyakit memang tidak terlihat oleh mata secara langsung dan bisa berasal dari mana saja. Tangan merupakan media penghantar utama penularan penyakit, karena tangan sering melakukan kontak langsung dengan berbagai benda atau area yang mengandung banyak kuman penyebab penyakit. Untuk mengatasi berbagai resiko penyakit tersebut maka biasakan untuk selalu mencuci tangan sebelum makan dan sesudah buang air besar atau buang air kecil dengan sabun. Berikut ini adalah berbagai resiko kesehatan jika tidak membiasakan mencuci tangan:

a. Mudah terkena pilek. Salah satu alasan utama rajin mencuci tangan adalah, untuk meminimalkan perpindahan virus dan bakteri ini akan memicu mudahnya untuk terkena pilek

b. Diare. Selain pilek, masalah kesehatan lain yang melalui proses serupa adalah diare.gangguan saluran pencernaan salah satunya ialah disebabkan oleh perpindahan virus atau bakteri melalui tangan kita hingga masuk ke saluran pencernaan oleh makanan yang kita pegang. c. Keracunan makanan. Tangan yang terkontabinasi bakteri, kuman, dan virus akan membantumu keracunan makanan dan kemudian berakhir dengan sakit perut akut, muntah, atau diare.

d. Hepatitis A. Hepatitis adalah penyakit yang disebabkan karena infeksi virus yang sangat menular pada organ hati. Salah satu proses yang memicu hepatitis $\mathrm{A}$ ialah virus dan bakteri yang masuk dan menulari tubuh kita jika jarang mencuci tangan.

e. Terinfeksi bakteri E.coli. E.coli atau Escherichia coli adalah bakteri yang menyebar dari kotoran sati orang ke orang lain. Tidak mencuci tangan setelah menggunakan toilet umum akan membantumu mudah terinfeksi bakteri ini.

f. Penyakit cairan tubuh. Cairan yang dikeluarkan tubuh mengandung banyak kuman, terutama saat kamu terinfeksi suatu penyakit. Begitu pula dengan tubuh orang lain. Saat kamu jarang cuci tangan, maka akan muncul penyakit yang berkaitan dengan cairan tubuh seperti tipus atau penyakit virus Epstein-bar.

g. Impetigo. Impetigo adalah infeksi menular yang biasa terjadi pada anak - anak yang jarang cuci tangan. Penyakit ini di tandai dengan kulit kemerahan yang kemudian berkembang menjadi lecet kecil.

Seperti yang disebutkan sebelumnya, cuci tangan adalah kegiatan yang sangat sederhana, boleh dikatakan sangatlah mudah untuk dilakukan. Namun, apabila malas, banyak resiko penyakit dan gangguan kesehatan akan sangat merugikan kita. Agar terhindar dari gangguan kesehatan akibat penularan virus dan bakteri, pastikan untuk lebih rajin mencuci tangan, dan akan lebih baik jika mencuci tangan dengan sabun.

\section{KESIMPULAN}

Hasil penelitian mendapatkan responden dengan katagori pengetahuan baik sebesar $54,2 \%$, sedangkan sebanyak $45,8 \%$ siswa Sekolah Dasar telah berperilaku baik dalam Cuci Tangan Pakai Sabun (CTPS). di sekolah belum disediakan fasilitas CTPS sehingga siswa tidak dapat mempraktikkan CTPS ketika berada di lingkungan sekolah. Untuk pihak Puskesmas hendaknya melakukan penyuluhan terhadap pengetahuan dan perilaku cuci tangan pakai sabun pada siswa di sekolah dasar dan pihak 
sekolah sebaiknya menyediakan fasilitas cuci tangan pakai sabun.

\section{DAFTAR PUSTAKA}

Depkes RI, 2008. Pedoman Pemantauan Status Gizi (PSG) dan Keluarga Sadar Gizi (Kadarzi). Jakarta: Depkes RI.

Kemenkes RI. 2011. Standar Antropometri Penilaian Status Gizi Anak. Jakarta: Direktorat Bina Gizi.

Kemenkes RI, 2014. Perilaku Mencuci Tangan Pakai Sabun di Indonesia. Jakarta: kemenkes RI
Notoatmodjo, Soekidjo. 2003. Pendidikan dan Perilaku Kesehatan, Jakarta, Rineka Cipta, 210 halaman.

Notoatmodjo, Soekidjo. 2012. Promosi Kesehatan dan Perilaku Kesehatan Edisi Revisi, Jakarta, Rineka Cipta, 248 halaman.

Notoatmodjo, Soekidjo, Ella Nurlela, Dkk. 2012, Promosi Kesehatan di Sekolah, Jakarta, Rineka Cipta, 170 halaman.

Proverawati dan Rahmawati, 2012. Perilaku hidup bersih dan sehat (PHBS). Yogyakarta: Nuha Medika. 